\title{
B. BOTULINUS (TYPE A) ASSOCIATED WITH FATAL PASTURE DISEASE OF HORSES
}

\author{
Robert Graham and Herman R. SCHWARze \\ From the Laboratory of Animal Pathology, Animal Husbandry Department, Unizersity of \\ Illinois, Urbana
}

For several years the writers have been studying, as the opportunity has been presented, the phenomena of an acute and subacute syndrome of horses grazing in pasture. The range and topography of the districts from which the outbreaks have been reported have suggested that the virus of the disease is rather widespread in nature or possibly indigenous to certain localities, though clarification of the epizootilogic facts, as well as the development of specific diagnostic and prophylactic measures, obviously await a definite knowledge of the causative factor or factors involved. If the conjecture relative to the widespread character of the virus is correct, it seems apparent that the sporadic appearance of the disease in pasture-fed horses is closely dependent on certain unknown natural influences which seasonally retard or facilitate the development of the disease and entrance to the host.

Since there is no assurance of the specificity of the remotely occurring outbreaks, it seems advisable in a preliminary survey to mention the fact that the feed has been suspected, though it has not been definitely incriminated. Pearson, ${ }^{1}$ Milks, ${ }^{2}$ Hickman, ${ }^{3}$ Mohler, ${ }^{4}$ Uhdall, Haslem, ${ }^{6}$ Stange ${ }^{7}$ and others have recognized the potentiality of a food poisoning in equine outbreaks of an epizootic and sporadic nature, though the agreement or disagreement regarding the relation of feed to the disease has been a matter of opinion rather than judgment based on specifically controlled experimental data. The clinical symptoms enumerated by different investigators are somewhat analogous, and at present constitute the only possible evidence of a common etiology.

A disease of horses occurring on pasture, which clinically resembles equine botulism, has been reported in several states, including eastern, southern and middle western localities. Inability to communicate or

\footnotetext{
Received for publication, March 11, 1921.

1 Report of State Veterinarian, Department of Agricuiture, Pennșylvania, 1902.

2 Louisiana Exper. Station Bull. 106, 1908.

- Bureau of Animal Industry, Department of Agriculture, Circular 122, 1906.

- Bureau of Animal Industry, Department of Agriculture, Bull. 65, 1914.

c Cornell Veterinarian, 1913.

G Kansas Exper. Station Bull. 173, 1910.

$\checkmark$ American Veterinary Review, 42, 1913.
} 
to transmit artificially the syndrome by blood inoculation or by association, together with negative bacteriologic findings in cultivating the aerobic flora of the visceral organs and heart's blood of fatally afflicted animals, has in a large measure stifled progress in the etiologic studies of the disease. In fact, the recorded results of laboratory investigations have repeatedly failed to explain the character of the losses in question, though negative findings in recent years have invited attention to the long neglected study of the anaerobes associated with certain spontaneous outbreaks of this or similar diseases.

Different phases of this investigation are still in progress, but since some time may elapse before a complete resumé will seem desirable. the authors are submitting a brief report on a portion of the bacteriologic work wherein attention has been given to the presence of sporebearing anaerobes. This report is based on the occurrence of a fatal endemic disease in horses which was brought to our attention through specimens presented for examination by Dr. J. H. McNeil, Chief of the Burcan of Animal Industry, Trenton, N. J.

\section{IIISTORY OF SPECIMENS}

An endemic disease of horses of varying severity has occurred in certain pasture districts in New Jersey for many years. The extent of the losses has been variable in different seasons, but the recurrence of the disease has attracted the attention of state sanitary officials. The majority of the severe outbreaks have been noted during the late summer and fall months, though sporadic cases have probably occurred throughout the year. The symptoms in affected horses, as observed by Dr. McNeil during the months of August, September, October, and November, 1920, suggested to him the possibility of a botulinus intoxication, though up to that time no evidence, to the knowledge of the writers, had been obtained to show that botulism occurred among grazing animals. The incidence of this disease in pasture-fed horses implied that botulinus toxin had developed in uncut grass or forage or that water supplies had been contaminated.

\section{B. BOTULINUS A SYMBIOTIC AEROBF}

In certain fatal, obscure, and toxemic-like diseases in domestic animals, sometimes referred to as forage poisoning, bacteriologic studies suggest that $\mathrm{B}$. botulinus, type $\mathrm{A}$ or $\mathrm{B}$, may have been a primary factor. The sporadic losses in question involved cattle, sheep, and swine 
throughout certain localities of the Mississippi Valley. In the same vicinities type A botulinus toxin was apparently a primary factor in the development of so-called "limber neck" of the domestic fowl. In these outbreaks harvested grain and forage, including ensilage, bakery refuse and restaurant garbage, and even certain mineral tonics prepared for animals, were found contaminated with B. botulinus. Each of these feeds apparently provided anaerobic conditions for the development of the toxin. B. botulinus has also been found in the intestinal contents and spleen and brain tissue of fatally afflicted animals, although evidence of growth in vivo with elaboration of toxin has not, in our studies, been observed.

The fact that $B$. botulinus is an anaerobe might lead to the belief that botulinus toxin would be excluded per se in pasture-fed animals. It does not necessarily follow, however, that anaerobiosis is essential to the development of the toxin. Growth of $B$. botulinus occurs aerobically in vitro in association with $B$. subtilus unprotected from light. Symbiotic development is also accompanied by the characteristic toxin production. Furthermore, it has been observed that the botulinus toxin in grain and hay is water diffusible, suggesting the possibility of the water supplies in improperly drained pasture lands becoming contaminated. In fact, certain outbreaks of a fatal disease in horses with manifest symptoms of botulism have been observed by veterinarians wherein the uncut grass and water of undrained fields were tentatively suspected. The relation of the water supplies to the disease in question should be intensively studied, although in the outbreak under discussion no attempt has been made by the writers to incriminate the water. It is apparent. from the results, however, that either the water or the grass or perhaps both, might be involved under certain conditions. The investigation of the outbreak in New Jersey has been restricted to the study of a strain of B. botulinus (type A) encountered in the spleen of typically afflicted animals following death.

\section{B. Botulinus (TYPE A) isolated FROM SPLEEN}

Several specimens, including spleen, brain and intestinal contents of fatally afflicted horses, together with a sample of hay from the pasture in which the horses had died, were subjected to bacteriologic study. One spleen specimen (539) proved to be contaminated with a 
gram-positive spore-bearing anaerobe, 0.9-1 by 3-8 mikrons, indistinguishable from $\mathrm{B}$. botulinus, type $\mathrm{A}$. The culturally sterile toxin produced by this strain in amounts of $0.00001 \mathrm{c} c$ is fatal in less than 24 hours to guinea-pigs weighing $250 \mathrm{gm}$. Antitoxin prepared from a

TABLE 1

Immunologic Relation of Strains $84 \quad$ AND 539

\begin{tabular}{|c|c|c|c|}
\hline \multirow{2}{*}{$\begin{array}{l}\text { Weight of } \\
\text { Guinea-Pigs } \\
\text { in Gm. }\end{array}$} & \multicolumn{2}{|c|}{$\begin{array}{c}\text { Tre atment Given at. } 10 \text { a. m., } \\
\text { Oct. } 26,1920\end{array}$} & \multirow[t]{2}{*}{ Rersults } \\
\hline & Antitoxin & Toxin 389 & \\
\hline 300 & \multirow{3}{*}{$\begin{array}{c}25 \text { units } A^{*} \\
(\text { No. } 84) \\
25 \text { units B } \\
(\text { No. } 126) \\
\ldots \ldots \ldots \ldots\end{array}$} & $0.3 \mathrm{ct}$ & Remained healthy \\
\hline 300 & & $0.3 \mathrm{cc}$ & Dead, 8 a. m., Oct. $2 \pi, 1920$ \\
\hline 300 & & $0.3 \mathrm{ec}$ & Tead, s p. m., Oct. 26,1920 \\
\hline
\end{tabular}

strain of B. botulinus, type A (84), isolated from olives, proved efficacious in protecting guinea-pigs against a lethal amount of toxin (539), as shown in table 1.

Antitoxin prepared from B. botulinus type A (539) apparently affords specific protection to guinea-pigs receiving fatal amounts of

TABLE 2

IMmUnologic Rejation of Strains 539 and 1500

\begin{tabular}{|c|c|c|c|}
\hline \multirow{2}{*}{$\begin{array}{l}\text { Weight of } \\
\text { Grinea-Pig: } \\
\text { in Gm. }\end{array}$} & \multicolumn{2}{|c|}{$\begin{array}{l}\text { Treatment Given at } 9 \text { a. m., } \\
\text { Jan. } 28,192 \mathrm{I}\end{array}$} & \multirow[t]{2}{*}{ Results } \\
\hline & Antitoxin & Toxin & \\
\hline 300 & $\begin{array}{l}25 \text { units } A^{*} \\
(\text { No. 539) }\end{array}$ & $\begin{array}{l}0.1 \text { ce spintach } \\
\text { Ifquort }\end{array}$ & Remained healthy \\
\hline 300 & $\begin{array}{l}25 \text { units B } \\
(\text { No. } 126)\end{array}$ & $\begin{array}{l}0.1 \text { e espinach } \\
\text { liquor } \\
\text { (No.150) }\end{array}$ & Dena, 8 p. m., Jan. 29,1021 \\
\hline 300 & $\ldots \ldots \ldots \ldots$ & $\begin{array}{c}\text { o.1 e e spinach } \\
\text { liquor } \\
\text { (No. 1500) }\end{array}$ & Dead, 8 p. m., Jan. 28,1121 \\
\hline
\end{tabular}

* Antitoxin given subcutuneously

+ Toxin given per os.

toxin from remotely isolated type A strains. The results of typing tests to determine the specificity of the antitoxin prepared from $B$. botulinus toxin (539) against type $A$ toxins present in the liquor of spinach (samples 1500 and 1592, associated with fatal outbreaks of botulism in man) are shown in tables 2 and 3 . 


\section{B. BOTULINUS NOT FOUND IN HAY}

Repeated bacteriologic examinations of a sample of hay from one of the suspected New Jersey pastures failed to reveal the presence of $B$. botulinus or other toxic anaerobes, though negative evidence in one sample cannot be considered conclusive regarding the relation of the hay or grass to the disease in question. The fact that the rations of the afflicted horses were limited to pasture grass implies that the toxin was probably present either in the uncut hay or in the water consumed by the affected animals. A toxic anaerobe was encountered in one speci-

TABLE 3

Immunologic Relation of Strains 539 and 1592

\begin{tabular}{|c|c|c|c|}
\hline \multirow{2}{*}{$\begin{array}{l}\text { Weight of } \\
\text { Guinea-Pigs } \\
\text { in Gm. }\end{array}$} & \multicolumn{2}{|c|}{$\begin{array}{c}\text { Treatment Given at } 9 \text { a. m., } \\
\text { Feb. } 15,1921\end{array}$} & \multirow[t]{2}{*}{ Results } \\
\hline & Antitoxin & Toxin & \\
\hline 275 & $\begin{array}{l}25 \text { units } A^{*} \\
(\text { No. 539) }\end{array}$ & $\begin{array}{l}0.1 \text { e e spinash } \\
\text { liquort } \\
\text { (No. 1592) }\end{array}$ & Remained healthy \\
\hline 275 & $\begin{array}{l}25 \text { units } B \\
\text { (No. 126) }\end{array}$ & $\begin{array}{l}0.1 \text { c e spinach } \\
\text { liquor } \\
\text { (No-1592) }\end{array}$ & Dead, 8 a, m., Feb. 16, 1921 \\
\hline 275 & $\ldots \ldots \ldots \ldots$ & $\begin{array}{c}0.1 \text { c e spinach } \\
\text { liquor } \\
\text { (No. 1592) }\end{array}$ & Dead, 8 a. m., Feb. $16,19 \cdot 1$ \\
\hline
\end{tabular}

men of intestinal contents, but in attempting to purify the strain and eliminate nonpathogenic types it was lost. Cultures from the brain of one specimen submitted proved negative to $B$. botulinus.

The bacteriologic and immunologic results of this investigation suggest to the authors that the losses experienced in certain New Jersey pasture-fed horses may be traceable to $B$. botulinus type $A$, though the relation, if any, of this intoxication to a similar enzootic disease of horses in remote outbreaks in other parts of America remains to be established.

\section{SUMMARY}

B. botulinus type A (539) was isolated from the spleen of a horse that displayed typical symptoms of an endemic syndrome occurring in certain pasture-fed horses in New Jersey.

In immunologic tests, as well as cultural examinations, this strain is indistinguishable from B. botulinus occurring in olives and spinach which proved to be the cause of outbreaks of botulism in man. 
On repeated examination the one sample of hay obtained from a pasture in which the horses had died proved free from B. botulinus and other toxic anaerobes.

Until the pathogenic and saprophytic characters of $B$. botulinus throughout its cycle in nature are more definitely established, the significance of the type A strain found in the equine spleen is not definitely concluded. In the light of our present knowledge, fortified by clinical evidence in afflicted animals, the bacteriologic findings herein recorded may be diagnostic of equine botulism. 